\title{
Deteksi Dini Pencegahan Karies Gigi Pada Anak dengan Cara Sikat Gigi di Paud Balqis, Asifa dan Tadzkiroh di Desa Babakan Kecamatan Ciparay Kabupaten Bandung
}

\author{
Tri Ardayani ${ }^{1}$, Hengki T Zandroto ${ }^{2}$ \\ Sekolah Tinggi Ilmu Kesehatan Immanuel Bandung, Jl Kopo No 161, Situsauer, Kecamatan \\ Bojongloa Kidul, Kota Bandung, Jawa Barat 40232 \\ Email: triardayani@gmail.com
}

\begin{abstract}
ABSTRAK
Karies gigi merupakan masalah yang sering ditemukan pada kesehatan gigi yang buruk, hal ini sering dialami oleh anak usia 4-6 tahun, dikarenakan anak belum mampu mengosok gigi dengan benar, pola makan yang buruk. Karies gigi dapat menganggu anak dalam beraktifitas, kurang konsentrasi, akibat lain dari karies gigi pada anak adalah penyebaran toksin atau bakteri pada mulut melalui aliran darah, saluran pernafasan, hal tersebut akan menyebabkan daya tahan tubuh anak menurun dan anak akan mudah terkena penyakit. Anak TK / PAUD tidak mengosok gigi, mengosok gigi adalah rutinitas kita sebaiknya 2 x dalam sehari, mengosok gigi sangatlah banyak manfaatnya, merawat gigi seperti mengosok gigi, membersihkan karang gigi, menghindari bau mulut, tidak terjangkit penyakit gusi. Hasil karakteristik survey kesehatan, prevalensi karies gigi pada balita usia 3-5 tahun sebesar $81.7 \%$. Prevalensi karies gigi menurut usianya usia 3 tahun $(60 \%)$, usia 4 tahun $(85 \%)$, dan usia 5 tahun $(86.4 \%)$ dengan demikian umur balita merupakan golongan rawan terjadi karies gigi. Usia anak menjaga kesehatan gigi memang tidak mudah untuk bisa mandiri merawat giginya, apalagi mengosok gigi dua kali sehari, pada usia dini, anak belum memahami pentingnya kesehatan gigi. Kesehatan gigi perlu diterapkan sejak usia dini, agar gigi mereka tumbuh dengan baik.
\end{abstract}

Kata Kunci: Deteksi Dini; Sikat Gigi; Karies Gigi

\begin{abstract}
Dental caries is a problem that is often found in poor dental health, and this is often experienced by children aged 4-6 years because children have not been able to brush their teeth properly, poor diet. Dental caries can disrupt children in their activities, lack of concentration, another result of dental caries in children is the spread of toxins or bacteria in the mouth through the bloodstream, respiratory tract, it will cause the child's immune system to decline, and the child will be susceptible to disease. Kindergarten / PAUD children do not brush their teeth, brushing their teeth is a routine we should do two times a day, brushing teeth is very beneficial, caring for teeth such as brushing teeth, cleaning tartar, avoiding bad breath, not contracting gum disease. The results of the characteristics of the health survey, the prevalence of dental caries in children aged 3-5 years by 81.7\%. The prevalence of dental caries according to age three years (60\%), age four years (85\%), and age five years $(86.4 \%)$ thus the age of toddlers is a group prone to occur dental caries. The age of the child to maintain dental health is indeed not easy to be able to independently care for his teeth, let alone brush his teeth twice a day, at an early age, children do not understand the importance of dental health. Dental health needs to be applied from an early age so that their teeth grow well.
\end{abstract}

Keywords: Early detection; Toothbrush; Caries toot 


\section{PENDAHULUAN}

Kesehatan gigi pada anak usia dini merupakan salah satu tumbuh kembang anak yang perlu diperhatikan. Sebuah studi mengatakan bahwa selama dekade terakhir penekanan telah ditempatkan pada pencegahan daripada pengobatan penyakit, oleh karena itu penting untuk menyadari bahwa pencegahan penyakit gigi merupakan peran penting dalam perawatan kesehatan pada anak secara keseluruhan. Kerusakan gigi yang terjadi pada anak dapat menjadi salah satu penyebab terganggunya pertumbuhan gigi anak pada usia selanjutnya (Oktarina, Tumaji, \& Roosihermiatie, 2016). Perhatian utama pada kesehatan gigi adalah kerusakan pada gigi-geligi primer. Karies anak usia dini, dimana gigi dapat menjadi busuk terjadi pada anak di bawah usia 6 tahun, adalah penyakit anak multi-faktorial dengan penentu sosial-budaya dan sosial ekonomi (Naidu, Nunn, \& Forde, 2012).

Karies gigi merupakan masalah kesehatan gigi yang cukup tinggi dialami di Indonesia dengan prevalensi lebih dari 80\% (Fatimatuzzahro, Prasetya, \& Amilia, 2016). Karies gigi terbentuk karena ada sisa makanan yang menempel pada gigi, yang pada akhirnya menyebabkan pengapuran gigi (Widayati, 2014). Masalah karies gigi pada anak usia dini membawa dampak yang cukup berbahaya yaitu gigi menjadi keropos, berlubang, bahkan patah sehingga membuat anak mengalami kehilangan daya kunyah dan mengganggu pencernaan (Widayati, 2014). Selain itu karies gigi dapat menyebabkan timbulnya rasa sakit pada gigi sehingga akan mengganggu penyerapan makanan dan memperngaruhi pertumbuhan anak hingga hilangnya waktu bermain anak karena sakit gigi (Fatimatuzzahro et al., 2016).

Pada anak usia dini gigi yang tumbuh merupakan gigi susu yang akan lepas dan berganti dengan gigi yang baru hal ini, menjadi perhatian penting dalam menjaga kesehatan gigi dengan mengajarkan pembiasaan menyikat gigi pada anak mulai dari usia dini sampai anak dewasa. Kesehatan gigi anak masih menjadi tanggungjawab dan perhatian orang tua, artinya anak masih bergantung kepada orang tua dalam menjaga dan merawat kesehatan giginya. Perilaku anak dalam menjaga kesehatan gigi biasanya ditunjukkan dengan cara menyikat gigi secara teratur. Pola makan dapat menjadi menyebab terjadinya karies gigi pada anak, karena anak usia dini masih sangat menggemari makanan dan minuman yang mengandung banyak gula. Kebiasaan anak yang mengkonsumsi makanan dan minuman yang banyak mengandung gula belum diimbangi dengan perawatan gigi yang baik dan benar (Widayati, 2014). 
Dampak yang ditimbulkan akibat karies gigi yang dialami anak-anak akan menghambat perkembangan anak sehingga akan menurunkan tingkat kecerdasan anak, yang secara jangka panjang akan berdampak pada kualitas hidup masyarakat (Widayati, 2014). Peningkatan kesehatan gigi dan mulut harus dimulai sedini mungkin, karena pada balita dan anak-anak prasekolah merupakan faktor yang sangat penting untuk pengaturan pertumbuhan gigi lebih lanjut. Selain itu, ini juga memengaruhi kemampuan anak untuk berbicara dan penguasaannya (Gigi, Bramantoro, Prabandari, Ismail, \& Tedjosasongko, 2015)

Usia anak-anak menjaga kesehatan gigi memang tidak mudah untuk bisa mandiri merawat giginya, apalagi mengosok gigi dua kali sehari, pada usia dini, anak-anak belum memahami pentingnya kesehatan gigi. Kesehatan gigi perlu diterapkan sejak usia dini, anak-anak perlu diajarkan tentang pentingnya mengosok gigi agar gigi mereka tumbuh dengan baik, kerusakan gigi dapat dicegah dengan mengosok gigi sebelum tidur malam dan setelah sarapan pagi, hal ini perlu diterapkan sejak kecil, oleh karena itu peran ibu, guru dan petugas kesehatan sangat diperlukan untuk membantu anak membersihkan gigi (Setiawan, 2016).

Pendidikan kesehatan gigi harus diperkenalkan sedini mungkin kepada anak agar mereka dapat mengetahui cara memelihara kesehatan giginya dan diharapkan orangtua, guru juga ikut berperan mengawasi kebersihan gigi anak-anaknya dengan mengajarkan cara menyikat gigi yang benar (Ghufron, 2016)

Hasil wawancara pada guru Paud Balqis, Asifa dan Tazkiroh yang dilakukan pada tanggal 30 Oktober 2018 didapatkan informasi bahwa ketiga Paud tersebut belum pernah ada penyuluhan tentang sikat gigi dan belum ada penelitian tentang sikat gigi. Hasil wawancara 10 orang anak Paud didapatkan 3 orang anak tidak melakukan sikat gigi dan 3 orang anak menyikat gigi pada saat pagi saja, 2 orang anak mengatakan tidak tahu kapan waktunya menyikat gigi, 2 orang anak mengatakan tidak tahu alasan kenapa harus menyikat gigi. Hasil observasi di dapatkan banyak masyarakat yang menjual makanan dan minuman manis yang dapat merusakan gigi dan didapatkan ada beberapa anak yang suka jajan coklat, es krim, permen.

Berdasarkan hal diatas saya tertarik untuk memberikan penyuluhan kesehatan gigi dan mengajarkan cara sikat gigi pada anak usia dini di Paud Balqis sehingga diharapkan setelah diberikan informasi yang diberikan pengetahuan anak bertambah tentang gigi sehat dan menyikat gigi dan anak dapat melakukan sikat gigi secara rutin sehingga jumlah anak yang mengalami karies gigi berkurang. Tujuan kegiatan pengabdian masyarakat yang di 
lakukan oleh Sekolah Tinggi Ilmu Kesehatan Immanuel Bandung di Paud Balqis, Asyifa dan Tadzkiron di Desa Babakan Kecamatan Ciparay Kabupaten Bandung adalah pengetahuan anak meningkat tentang gigi sehat dan cara sikat gigi serta dapat mengubah kebiasaan anak untuk rutin melakukan sikat gigi maksimal 2 kali sehari (pagi dan malam hari).

Masalah yang di temukan di tiga paud tersebut ( Balqis, Asyifa dan Tadzkiroh) banyak warung yang menjual makanan/jajanan manis yang disukai oleh anak, belum pernah ada informasi penyuluhan kesehatan tentang cara sikat gigi, hasil pemeriksaan banyak gigi anak-anak yang karies, berwarna hitam-hitam, ada anak yang tidak masuk sekolah karena sakit gigi, anak mengosok gigi hanyak 1 kali terkadang tidak mengosong gigi karena tidak tahu kenapa harus mengosok gigi, tidak mengetahui kapan waktunya menyikat gigi dan anak belum mengetahui bagaimana cara menyikat gigi dengan benar.

Target luaran yang diharapkan adalah : meningkatkan pengetahuan anak paud tentang gigi yang sehat, meningkatkan pengetahuan anak paud jajanan yang sehat dan tidak merusak gigi, meningkatkan pengetahuan anak paud makanan yang sehat untuk gigi, meningkatkan pengetahuan anak paud dampak/akibat jika tidak mengosok gigi, membantu bekerjasama dengan guru dan orang tua dalam menjaga gigi anak agar tidak karies, mengajarkan kepada anak paud cara menyikat gigi dengan benar, membuat video tentang cara menyikat gigi dengan benar agar mudah dimengerti oleh anak.

\section{METODE}

Metode yang digunakan untuk mengwujudkan tujuan tersebut dengan melakukan tindak partisipatif antara pihak sekolah dan sekolah tinggi ilmu kesehatan Immanuel tentang kegiatan yang akan dilakukan. Metode pelaksanaan tersebut meliputi:

A. Pendidikan kesehatan kepada anak Paud Balqis

Pendidikan kesehatan pada paud Balqis di lakukan dalam 2 tahap yaitu memberikan penyuluhan dan mengajarkan bagaimana cara menyikat gigi dengan benar (praktek menyikat gigi) kegiatan di lakukan pada tanggal tanggal 22 November 2018 jam 09.00 wib s.d 09.30 wib pada anak usia 3 sampai 5 tahun sebanyak 16 orang. Materi yang diberikan meliputi: pengertian gigi sehat, pengertian mengosok gigi, manfaat mengosok gigi, waktu mengosok gigi. Kegiatan kedua praktek cara mengosok gigi dengan benar (dengan menggunakan peralatan sikat gigi langsung masing-masing anak menyikat gigi sendiri). 
Narasumber dalam kegiatan pengabdian masyarakat ini adalah dosen kesehatan masyarakat di bantu oleh 3 mahasiswa dari prodi kesehatan masyarakat.

B. Pendidikan kesehatan kepada anak Paud Asyifa

Pendidikan kesehatan pada paud Asyifa di lakukan dalam 2 tahap yaitu memberikan penyuluhan dan mengajarkan bagaimana cara menyikat gigi dengan benar (praktek menyikat gigi) kegiatan di lakukan pada tanggal tanggal 21 November 2018 jam 09.00 wib s.d 09.30 wib pada anak usia 3 sampai 5 tahun sebanyak 17 orang. Materi yang diberikan meliputi: pengertian gigi sehat, pengertian mengosok gigi, manfaat mengosok gigi, waktu mengosok gigi. Kegiatan kedua praktek cara mengosok gigi dengan benar (dengan menggunakan peralatan sikat gigi langsung masing-masing anak menyikat gigi sendiri). Narasumber dalam kegiatan pengabdian masyarakat ini adalah dosen kesehatan masyarakat di bantu oleh 3 mahasiswa dari prodi kesehatan masyarakat.

C. Pendidikan kesehatan kepada anak Paud Tadzkiroh

Pendidikan kesehatan pada paud Asyifa di lakukan dalam 2 tahap yaitu memberikan penyuluhan dan mengajarkan bagaimana cara menyikat gigi dengan benar (praktek menyikat gigi) kegiatan di lakukan pada tanggal tanggal 27 November 2018 jam 10.00 wib s.d 10.30 wib pada anak usia 3 sampai 5 tahun sebanyak 32 orang. Materi yang diberikan meliputi: pengertian gigi sehat, pengertian mengosok gigi, manfaat mengosok gigi, waktu mengosok gigi. Kegiatan kedua praktek cara mengosok gigi dengan benar (dengan menggunakan peralatan sikat gigi langsung masing-masing anak menyikat gigi sendiri). Narasumber dalam kegiatan pengabdian masyarakat ini adalah dosen kesehatan masyarakat di bantu oleh 3 mahasiswa dari prodi kesehatan masyarakat.

\section{HASIL, PEMBAHASAN, DAMPAK}

Hasil dan pembahasan pengabdian masyarakat ini antara lain:

1. Pendidikan kesehatan kepada anak Paud Balqis Tujuan dari pengabdian masyarakat ini dapat meningkatkan pengetahuan dapat membantu anak dalam melakukan sikat gigi dan dapat membantu anak dalam pencegahan karies gigi antara lain: pengertian gigi sehat, pengertian mengosok gigi, manfaat mengosok gigi, waktu mengosok gigi. Kegiatan kedua praktek cara mengosok gigi dengan benar (dengan menggunakan peralatan sikat gigi langsung 
masing-masing anak menyikat gigi sendiri). Target luaran yang di capai : anak Paud Balqis yang mengikuti kegiatan pengabdian masyarakat ini sebanyak 16 orang.

Hasil pengabdian masyarakat di Paud Balqis didapatkan hasil pengetahuan anak meningkat tentang gigi sehat dan cara menyikat gigi dengan benar, anak dapat menjawab pertanyaan yang diajukan oleh narasumber. Dampak yang didapatkan dari penyuluhan kesehatan di Paud Balqis anak pengetahui tujuan mengosok gigi, kapan waktu menyikat gigi sehingga anak dapat menerapkan dirumah menyikat gigi yang sudah diajarkan oleh narasumber.

2. Pendidikan kesehatan kepada anak Paud Asyifa

Tujuan dari pengabdian masyarakat ini dapat meningkatkan pengetahuan dapat membantu anak dalam melakukan sikat gigi dan dapat membantu anak dalam pencegahan karies gigi antara lain : pengertian gigi sehat, pengertian mengosok gigi, manfaat mengosok gigi, waktu mengosok gigi. Kegiatan kedua praktek cara mengosok gigi dengan benar (dengan menggunakan peralatan sikat gigi langsung masing-masing anak menyikat gigi sendiri). Target luaran yang di capai : anak Paud Balqis yang mengikuti kegiatan pengabdian masyarakat ini sebanyak 17 orang.

Hasil pengabdian masyarakat yang dilakukan di Paud Asyifa pengetahuan anak meningkat tentang gigi sehat dan cara menyikat gigi dengan benar, anak dapat menjawab pertanyaan yang diajukan oleh narasumber, dan anak dapat melakukan langkah-langkah menyikat gigi dengan benar. Dampak penyuluhan yang sudah diberikan pada anak Paud Asyifa anak mengetahui makanan, minuman atau jajanan yang dapat merusak gigi sehingga anak mengurangi untuk jajan yang dapat merusak gigi.

3. Pendidikan kesehatan kepada anak Paud Tadzkiroh

Tujuan dari pengabdian masyarakat ini dapat meningkatkan pengetahuan dapat membantu anak dalam melakukan sikat gigi dan dapat membantu anak dalam pencegahan karies gigi antara lain : pengertian gigi sehat, pengertian mengosok gigi, manfaat mengosok gigi, waktu mengosok gigi. Kegiatan kedua praktek cara mengosok gigi dengan benar (dengan menggunakan peralatan sikat gigi langsung masing-masing anak menyikat gigi sendiri). Target luaran yang di capai : anak Paud Balqis yang mengikuti kegiatan pengabdian masyarakat ini sebanyak 32 
orang. Peserta anak menyebutkan kembali materi yang sudah disampaikan dan dapat mempraktekkan kembali cara menyikat gigi.

Hasil pengabdian masyarakat didapatkan pengetahuan anak meningkat tentang gigi sehat dan cara menyikat gigi, anak dapat menjawab pertanyaan yang diajukan oleh narasumber dan anak dapat mempraktekkan cara menyikat gigi dengan benar. Dampak penyuluhan kesehatan pada Paud Tazdkiroh anak mengetahui untuk mendapatkan gigi yang sehat harus makan sayur dan buah yang sehat sehingga anak mulai membiasakan untuk makan sayur dan buah yang sehat untuk mencegah karies gigi dan anak dapat menyiapkan alat - alat yang butuhkan untuk menyikat gigi dirumah.

\section{Dokumentasi Kegiatan Pengabdian Masyarakat}

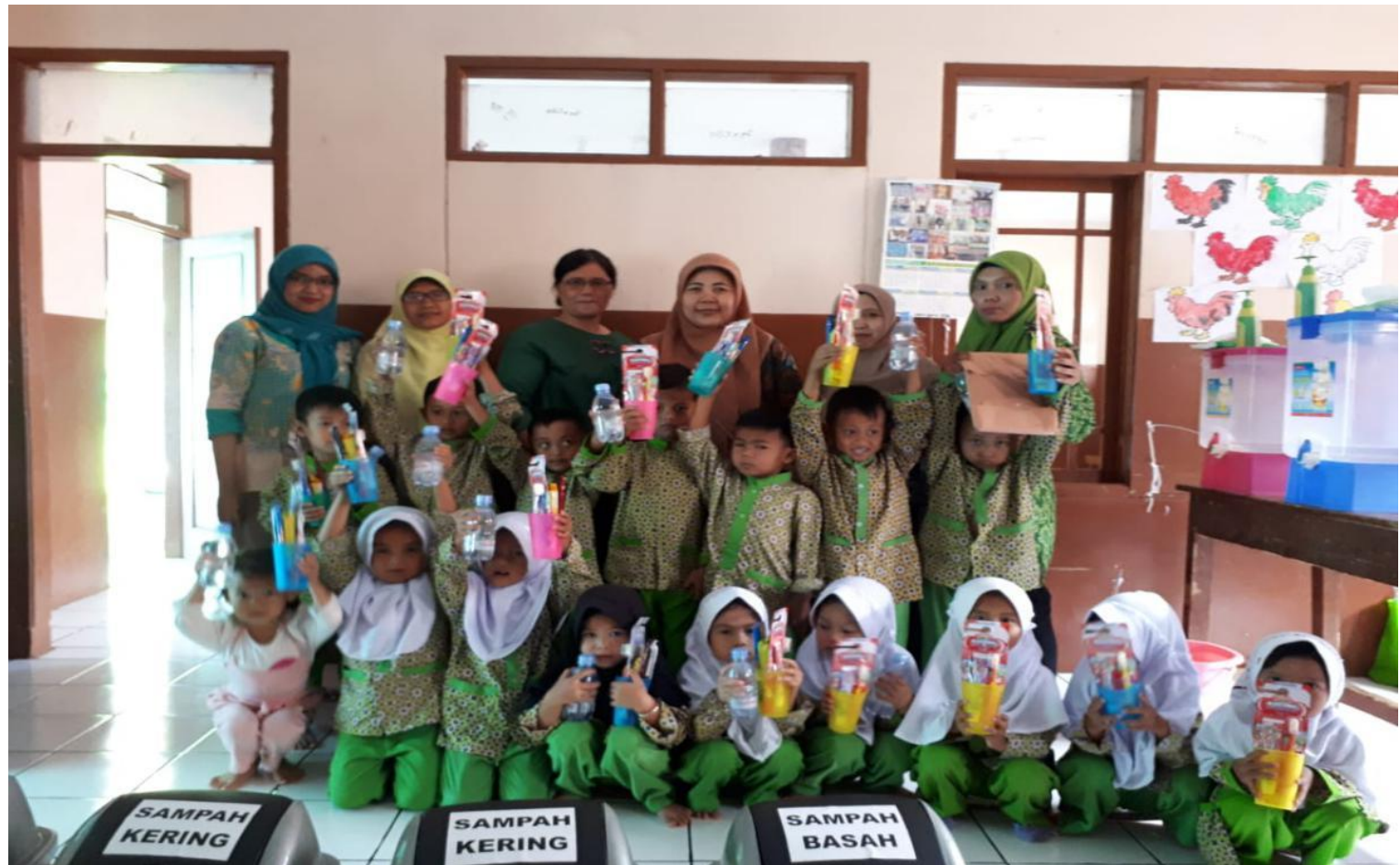

Gambar 1 : Membagikan Alat- Alat Yang di Butuhkan Untuk Menyikat Gigi Pada Anak Di Paud 


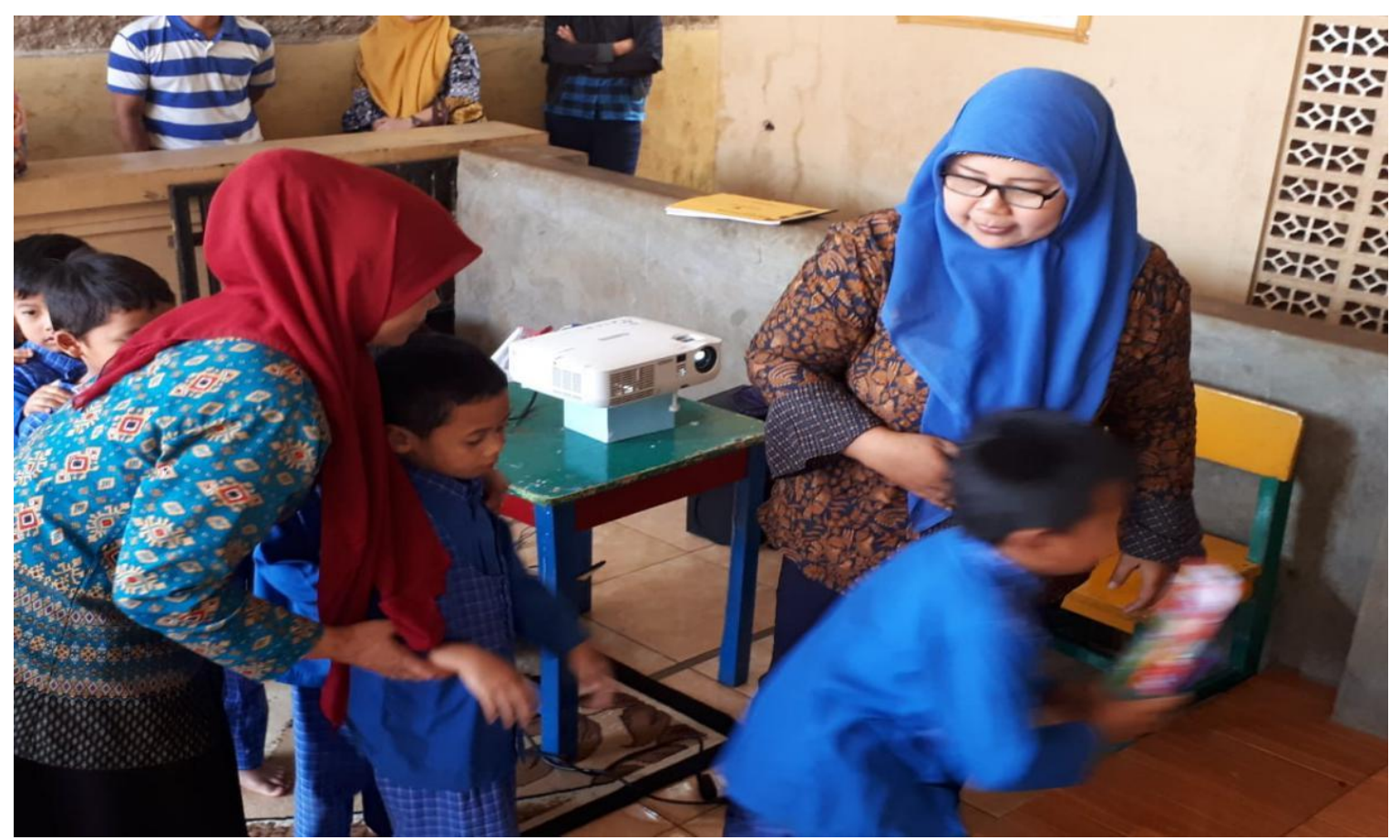

Gambar 2 : Memberikan Pertanyaan dan Hadiah Pada Anak Yang Bisa Menjawab Di Paud Tadzkiroh

\section{SIMPULAN}

Kesehatan gigi pada anak usia dini merupakan salah satu tumbuh kembang anak yang perlu diperhatikan. Kerusakan gigi yang terjadi pada anak dapat menjadi salah satu penyebab terganggunya pertumbuhan gigi anak pada usia selanjutnya. Karies gigi terbentuk karena ada sisa makanan yang menempel pada gigi, yang pada akhirnya menyebabkan pengapuran gigi, gigi menjadi keropos, berlubang, bahkan patah sehingga membuat anak mengalami kehilangan daya kunyah dan mengganggu pencernaan, selain itu karies gigi dapat menyebabkan timbulnya rasa sakit pada gigi sehingga akan mengganggu penyerapan makanan dan memperngaruhi pertumbuhan anak hingga hilangnya waktu bermain anak karena sakit gigi.

Pada anak usia dini gigi menjadi perhatian penting dalam menjaga kesehatan gigi dengan mengajarkan pembiasaan menyikat gigi pada anak mulai dari usia dini sampai anak dewasa. Kesehatan gigi anak masih menjadi tanggungjawab dan perhatian orang tua, artinya anak masih bergantung kepada orang tua dalam menjaga dan merawat kesehatan giginya. Perilaku anak dalam menjaga kesehatan gigi biasanya ditunjukkan dengan cara menyikat gigi secara teratur. Pola makan dapat menjadi menyebab terjadinya karies gigi pada anak, karena anak usia dini masih sangat menggemari makanan dan minuman yang mengandung banyak gula. Kebiasaan anak yang mengkonsumsi makanan dan minuman yang banyak mengandung gula belum diimbangi dengan perawatan gigi yang baik dan benar.

Dampak yang ditimbulkan akibat karies gigi yang dialami anak-anak akan menghambat perkembangan anak sehingga akan menurunkan tingkat kecerdasan memngaruhi kemampuan anak untuk berbicara dan penguasaannya. Sehingga anak mulai dari usia dini harus di beri pengetahuan tentang pentingya menjaga gigi dengan cara 
mengurangi /menghindari makanan dan minuman yang dapat merusak gigi, menyikat gigi sekurang-kurangnya 2 x sehari dan melakukan kontrol gigi setiap 6 bulan sekali untuk menghindari karies gigi.

\section{DAFTAR PUSTAKA}

Fatimatuzzahro, N., Prasetya, R. C., \& Amilia, W. (2016). Gambaran Perilaku Kesehatan Gigi Anak Sekolah Dasar di Desa Bangalsari Kabupaten Bantaeng. Jurnal IKESMA, 12(2), 85 .

Gigi, M. K., Bramantoro, T., Prabandari, Y. S., Ismail, D., \& Tedjosasongko, U. (2015). The development of early childhood caries impact on quality of life - Indonesia instrument as assessment instrument of dental caries impact on quality of life of children aged 3-5 years based on Indonesian community characteristics, 197(56), 197-203. https://doi.org/10.20473/j.djmkg.v48.i 4.p197-203

Ghufron, M, 2016. Perbedaan Efektifitas Menyikat Gigi dengan Kayu Siwak dan Sikat Gigi Konvensional Terhadap Penurunan Indeks Plak.

Naidu, R., Nunn, J., \& Forde, M. (2012). Oral healthcare of preschool children Trinidad: a qualitative study of parents and caregivers. BMC Oral Health, 12(1), 1. https://doi.org/10.1186/1472-6831-

Oktarina, Tumaji, \& Roosihermiatie, B. (2016). Korelasi Faktor Ibu Dengan Status Kesehatan Gigi Dan Mulut Taman Kanak-Kanak di Kelurahan Kemayoran Kecamatan Krembangan, Kota Surabaya. Pusat Penelitian Dan Pengembangan Humaniora Dan Manajemen Kesehatan, 19(17), 226-235.

Widayati N. Faktor yang berhubungan dengan karies gigi pada anak usia 4-6 tahun. Jurnal Berkala Epidemiologi [serial online] 17 April 2020 ;2(2):196-205. Available from: URL: http://journal.unair.ac.id 